\title{
MODERN AND PLEISTOCENE RESERVOIR AGES INFERRED FROM SOUTH PACIFIC CORALS
}

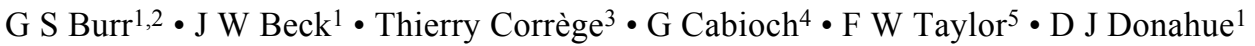

ABSTRACT. This paper presents radiocarbon results from modern South Pacific corals from the Marquesas Islands, Vanuatu, Papua New Guinea (PNG), and Easter Island. All of the measurements are from pre-bomb Porites corals that lived during the 1940s and 1950s. The data reflect subannual to multiannual surface ocean ${ }^{14} \mathrm{C}$ variability and allow for precise, unambiguous reservoir age determinations. The results are compared with published values from other coral records throughout the South Pacific, with striking consistency. By comparisons with other published values, we identify 3 South Pacific regions with uniform pre-bomb reservoir ages (1945 to 1955). These are 1) the Central Equatorial South Pacific (361.6 \pm 8.2 ${ }^{14} \mathrm{C}$ yr, $\left.\left.2 \sigma\right) ; 2\right)$ the Western Equatorial South Pacific $\left(322.1 \pm 8.6{ }^{14} \mathrm{C}\right.$ yr, $\left.2 \sigma\right)$; and 3$)$ the subtropical Pacific $\left(266.8 \pm 13.8{ }^{14} \mathrm{C}\right.$ $\mathrm{yr}, 2 \sigma)$.

The question of how much, and how fast, South Pacific reservoir ages might have varied in the past is addressed by examining a published record from a Pleistocene coral from Vanuatu that lived over a 700 -yr period during the Younger Dryas. The average reservoir age at that time was larger than today, by $\sim 150 \mathrm{yr}$, and exhibited reservoir age variability on a decadal timescale not seen in modern times. Measured paleo-reservoir ages increase sharply in this record by as many as $300{ }^{14} \mathrm{C}$ yr in 3 decades. These increases are punctuated by smaller reservoir age decreases, on the order of $150 \mathrm{yr}$. This reservoir age variability provides a rare picture of active ocean ventilation and ocean-atmosphere exchange at the close of the Pleistocene.

\section{INTRODUCTION}

The marine reservoir effect has long been a topic of interest in radiocarbon research. The first marine reservoir age determination was published by Craig (1954). He measured the ${ }^{14} \mathrm{C}$ content of dissolved inorganic carbon (DIC) from the Atlantic Ocean and Mediterranean Sea, and observed a $5 \%$ difference between ocean and atmosphere. From this, he calculated a marine reservoir age of $\sim 400$ yr. He attributed this difference to the time required for air-sea exchange and internal oceanic mixing. Craig emphasized that both of these processes are significantly slower than mixing within the atmosphere, and he was able to rule out isotopic fractionation as the cause of the ${ }^{14} \mathrm{C}$ depletion by comparison with ${ }^{13} \mathrm{C}$ data. The next step to understanding the exchange of ${ }^{14} \mathrm{C}$ between the ocean and atmosphere came with the development of carbon cycle box models that considered the exchange in the context of a larger system (Craig 1957; Revelle and Suess 1957). Oeschger et al. (1975) refined this approach, by treating the deep sea as a diffusive medium with constant vertical eddy diffusivity instead of a well-mixed reservoir. Their model became the standard for ${ }^{14} \mathrm{C}$ reservoir age studies (Hughen et al. 2004). Today, ${ }^{14} \mathrm{C}$ continues to be utilized as an indicator of upwelling processes and ocean ventilation, and ${ }^{14} \mathrm{C}$ measurements are a critical component of modeling studies of past and present climate (Guilderson et al. 2000a; Matsumoto et al. 2004; Rodgers et al. 2004; Müller et al. 2006; Meissner 2007; Franke et al. 2008; Singarayer et al. 2008).

Marine reservoir ages alone serve as a qualitative measure of mixing between the surface and deep ocean, with the unlikely units of ${ }^{14} \mathrm{C}$ yr BP. They also make it possible to calculate ${ }^{14} \mathrm{C}$ ages of marine samples. Stuiver et al. (1986) describe 2 means of calibrating reservoir-corrected marine ${ }^{14} \mathrm{C}$ ages: 1) by measuring the marine reservoir age directly (in ${ }^{14} \mathrm{C} \mathrm{yr}$ ), and subtracting this value from

${ }^{1}$ NSF-Arizona AMS Laboratory, University of Arizona, Physics Department, Tucson, Arizona 85721-0081, USA.

2Department of Geosciences, National Taiwan University, Taipei, Taiwan. Corresponding author. Email: burr@u.arizona.edu. ${ }^{3}$ Université Bordeaux 1, Avenue des Facultés 33405 Talence Cedex, France.

${ }^{4}$ IRD, UMR LOCEAN, Centre d'Ile de France 32, avenue Henri Varagnat 93143 Bondy Cedex, France.

${ }^{5}$ Institute for Geophysics, J.J. Pickle Research Campus, Bldg. 196, 10100 Burnet Road (R2200), Austin, Texas 78758-4445, USA.

(C) 2009 by the Arizona Board of Regents on behalf of the University of Arizona Celebrating 50 Years of Radiocarbon

RADIOCARBON, Vol 51, Nr 1, 2009, p 319-335 
the sample for subsequent comparison with the atmospheric calibration curve; or 2) by using a marine calibration curve that incorporates the reservoir correction into it. The latter technique involves the use of a marine model to estimate reservoir ages through time. It has the advantage that it can be applied globally, but depends on knowledge of the reservoir age for a particular locality (Hughen et al. 2004; Reimer and Reimer 2006). The former technique is more direct and unambiguous, but requires that the reservoir correction for a given site be known at the time the sample formed. Corals offer a potential archive that can provide this information.

Corals that form annual bands are well known for their use as proxies of ocean chemistry, ocean circulation, and climate (Druffel 1997). These proxies include ${ }^{14} \mathrm{C}$, which can be used to directly measure marine reservoir ages by comparison with known atmospheric ${ }^{14} \mathrm{C}$ values. Corals have several advantages over other archives used to determine reservoir ages. For example, they are sessile organisms that produce skeletons from carbon acquired from DIC in seawater. There is no question about the source of carbon or where it was acquired. The calendar age of modern samples (up to $500 \mathrm{yr}$ old) can be established directly by counting annual growth bands, and paleocorals can be accurately dated with U/Th and ${ }^{231} \mathrm{~Pa}$ techniques (Edwards et al. 1987; Cutler et al. 2004). Corals are widespread and common throughout the South Pacific, and many live for decades to centuries, so very long records can be constructed, with annual to subannual resolution. The longest modern coral ${ }^{14} \mathrm{C}$ records studied thus far include a $\sim 320$-yr record from the Great Barrier Reef (Druffel and Griffin 1993) and a 370-yr record from the Galapagos (Druffel et al. 2007).

The purpose of this paper is to assess the reservoir age variability in South Pacific coral records. We report 4 new pre-bomb records from the 1940s and 1950s and compare these to existing records published in the literature. We then examine a published South Pacific paleocoral record from the Younger Dryas (Burr et al. 1998) to constrain both the reservoir age at that time, and the rate at which it changed between $\sim 11.8$ and $12.3 \mathrm{kyr}$ BP. This paper is restricted to coral results. A recent comprehensive review of South Pacific reservoir ages from a spectrum of natural archives is given by Petchey et al. (2008).

\section{SAMPLING SITES}

The ${ }^{14} \mathrm{C}$ content of a coral is a reflection of its physical oceanographic setting, and coral-based ${ }^{14} \mathrm{C}$ time series are often used to examine changes in surface flow and upwelling through time. Specific coral sites give us different information. For example, ${ }^{14} \mathrm{C}$ records from corals in the Galapagos Islands are very sensitive to El Niño events (Druffel 1981; Brown et al. 1993; Guilderson and Schrag 1998) as well as climatic factors (Druffel et al. 2007). ${ }^{14} \mathrm{C}$ records from Fanning Island corals depend on the phase of the Pacific Decadal Oscillation (Grottoli et al. 2004), and $\Delta^{14} \mathrm{C}$ coral records from Indonesia are indicative of their source waters (Moore et al. 1997) and monsoonal climatic influences (Fallon and Guilderson 2008). In this study, the aim was to find corals that represent broad regions of the South Pacific for the purpose of constraining marine reservoir ages. With this in mind, live samples of Porites were drilled from corals along the coasts of the Marquesas Islands $\left(9^{\circ} \mathrm{S}, 140^{\circ} \mathrm{W}\right)$; Espiritu Santo Island, Vanuatu $\left(15^{\circ} \mathrm{S}, 167^{\circ} \mathrm{E}\right)$; Rabaul, Papua New Guinea $\left(4^{\circ} \mathrm{S}\right.$, $\left.152^{\circ} \mathrm{E}\right)$; and Easter Island, Chile $\left(27^{\circ} \mathrm{S}, 109^{\circ} \mathrm{W}\right)$ (Figure 1). The first 3 sites are in the tropics, all in the path of the South Equatorial Current (SEC). These were selected to provide a broad east-west profile for the South Pacific. The Easter Island site is a subtropical site in the central portion of the South Pacific Subtropical Gyre, far removed from the direct influence of the SEC. The difference in surface flow regime at Easter Island, as compared with the other sites, is evident in surface velocity time series averaged over the past $15 \mathrm{yr}$ (Figure 2). Surface zonal current velocities at Easter Island are from west to east and relatively weak, as compared to the tropical sites. Zonal currents at the 


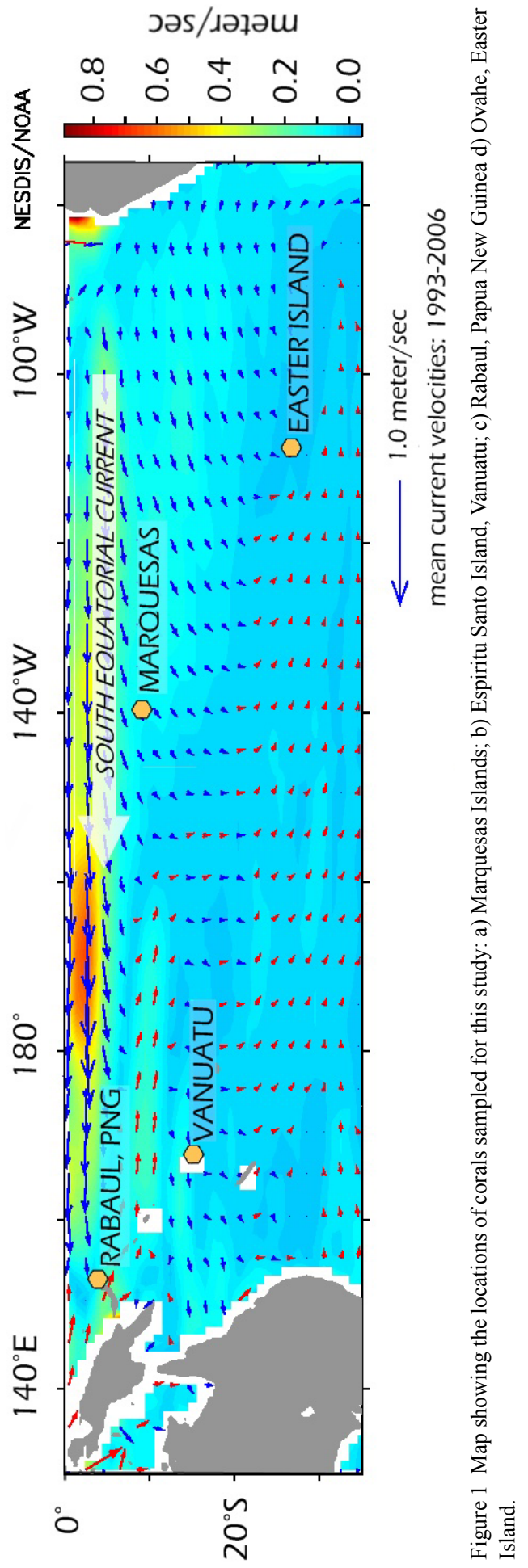



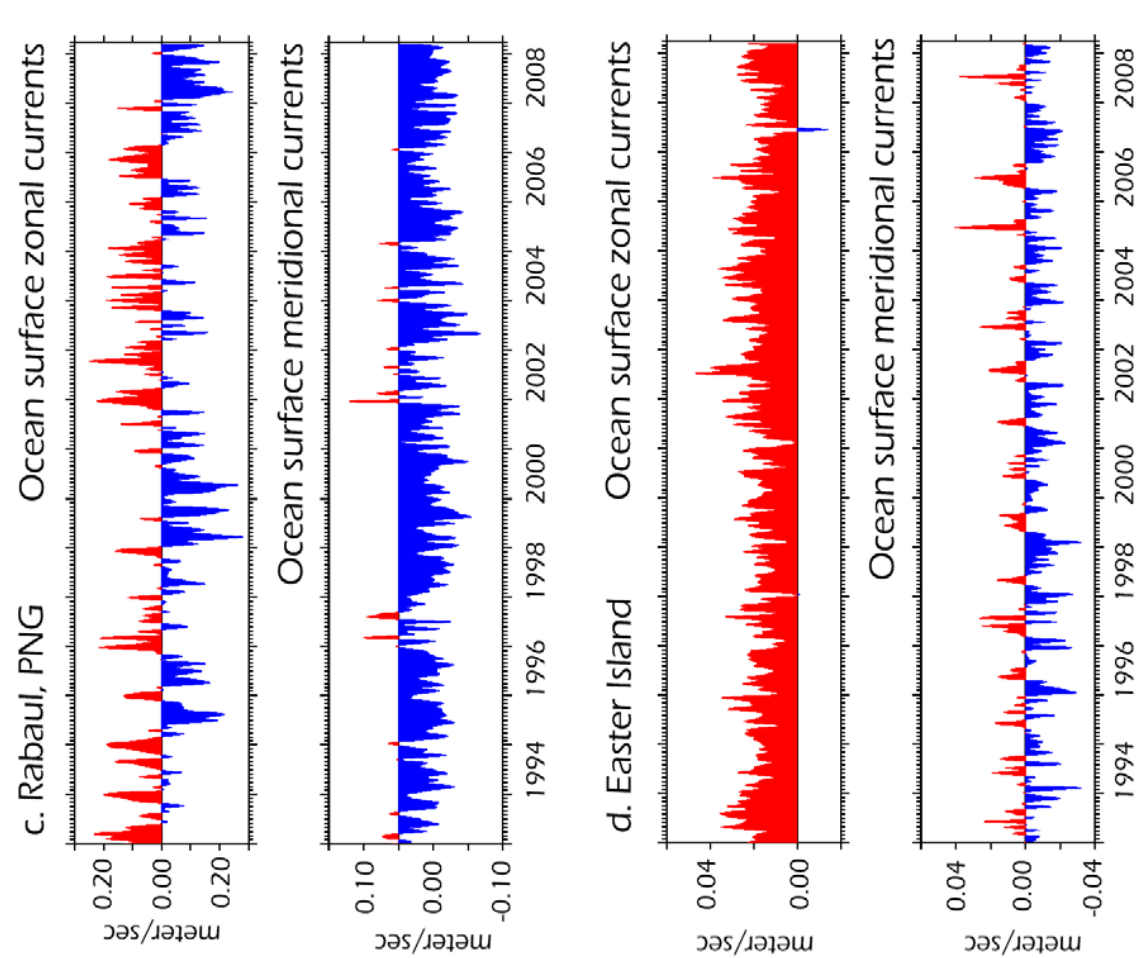

३ें

in 彳亍 守豆

竞

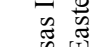

政

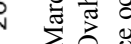

बิि

is

$>0$

至

कि

눙

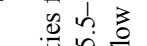

它递

융

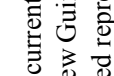

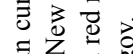

造
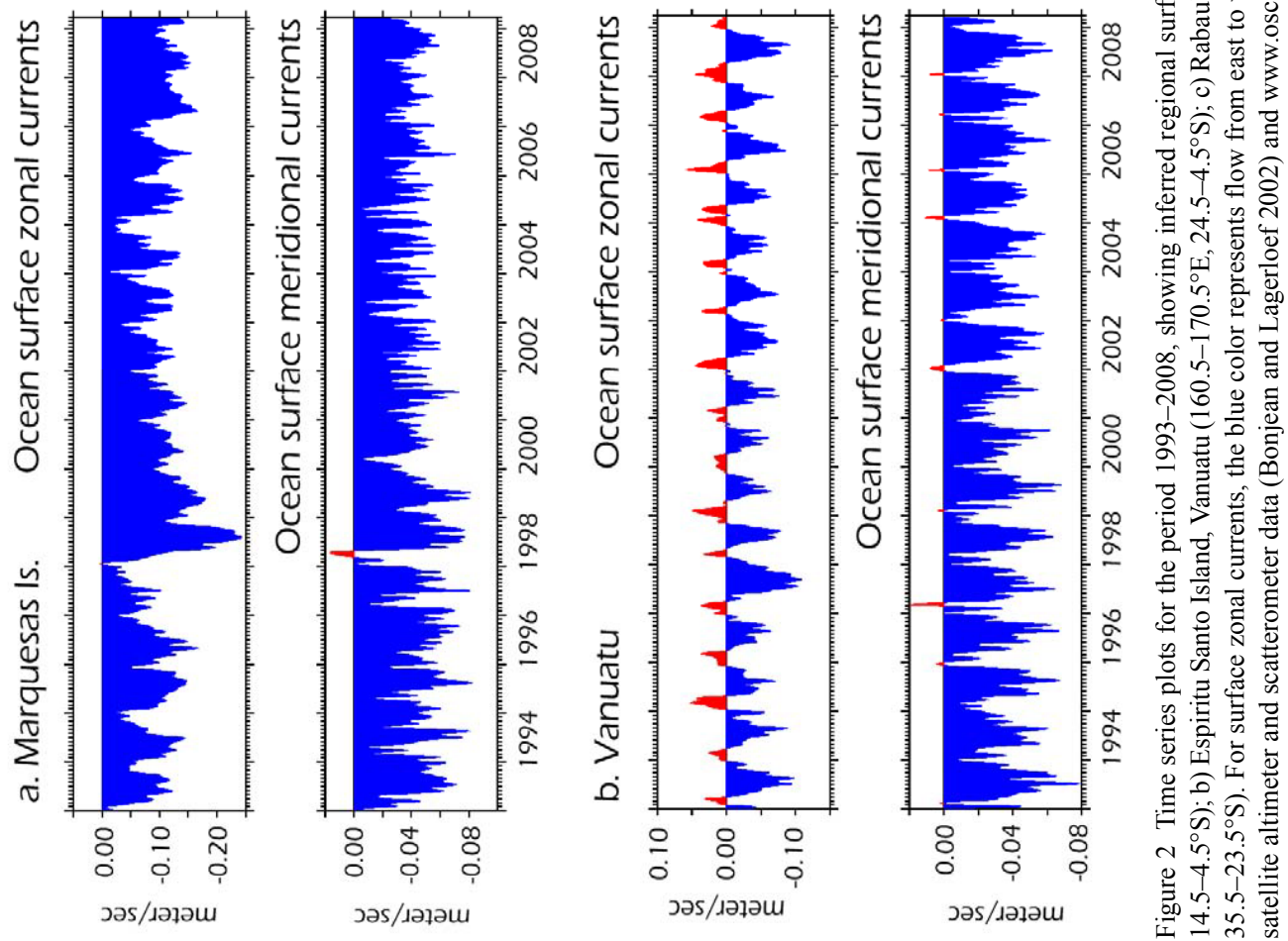
Marquesas Islands travel from east to west year-round. This contrasts with the direction of zonal current flow at Rabaul and Espiritu Santo, where seasonal alternating current directions are observed (Figure 2). Hence, although the 3 tropical sites are all in the path of the SEC, their individual surface ocean current characteristics represent a range of surface flow conditions.

\section{METHODS}

\section{Sample Measurement}

Samples were obtained using underwater hydraulic drilling equipment. Vertical cores were taken parallel to the growth axes of the corals, from approximately the center of the top surface of each colony. The cores were cut in half along their length with a diamond saw, and 5-mm-thick slabs were made from half of each core. The slabs were X-rayed to identify subannual growth bands. A year of growth corresponds to 1 light and dark band couplet on an X-ray image. Each band was sampled to provide a minimum time resolution on the order of 6 months. In some cases, additional subsamples were taken with a maximum resolution of $\sim 2$ months. Each piece of coral was completely dissolved to produce $\mathrm{CO}_{2}$, which was reduced to graphite for accelerator mass spectrometry (AMS) analysis. In most cases, a split of the $\mathrm{CO}_{2}$ was taken to determine the $\delta^{13} \mathrm{C}$ value of the sample using a conventional mass spectrometer.

\section{Reservoir Age Calculations}

The reservoir age of a marine sample is defined as the offset between its ${ }^{14} \mathrm{C}$ age and the ${ }^{14} \mathrm{C}$ age of the contemporaneous atmosphere (Stuiver and Polach 1977; Stuiver et al. 1986; Stuiver and Braziunas 1993):

$$
R(t)={ }^{14} \mathrm{C} \text { age of marine sample }-{ }^{14} \mathrm{C} \text { age of atmospheric sample }
$$

where a positive $R$ value indicates that the marine sample is relatively older than the atmospheric age (the usual case). Reservoir ages are site-specific and depend principally on the physical oceanographic setting of a particular region. $R$ also varies with time $(t)$, depending on a variety of factors such as surface ocean circulation, atmospheric ${ }^{14} \mathrm{C}$ production, and exchange rates between terrestrial carbon pools.

To quantify a reservoir age using AMS, the first step is to measure fraction modem carbon $(F)$ values, defined as:

$$
F=\left({ }^{14} \mathrm{C} /{ }^{13} \mathrm{C}\right)_{S} /\left({ }^{14} \mathrm{C} /{ }^{13} \mathrm{C}\right)_{S T D}
$$

where $\left({ }^{14} \mathrm{C} /{ }^{13} \mathrm{C}\right)_{S}$ is the measured ratio in the sample, normalized to $\delta^{13} \mathrm{C}=-25 \%$, and $\left({ }^{14} \mathrm{C} /{ }^{13} \mathrm{C}\right)_{S T D}$ is the calculated modern standard ratio at AD 1950, determined from measurements of NBS oxalic acid standards, also normalized to $-25 \%$ (Donahue et al. 1990). The ${ }^{14} \mathrm{C}$ age of a sample is then calculated from $F$ as:

$$
{ }^{14} \mathrm{C} \text { age }=-8033 \ln F
$$

Substituting Equation 3 into Equation 1 for a fixed $t$, gives a result for the reservoir age in terms of F:

$$
R=8033 \ln \left(\frac{F_{a t m}}{F_{\text {mar }}}\right)
$$


where $F_{\text {atm }}$ is a measure of the ${ }^{14} \mathrm{C}$ content of the atmosphere and $F_{\text {mar }}$ is a measure of the ${ }^{14} \mathrm{C}$ content of the surface ocean. This equation can be applied to contemporaneous marine and atmospheric samples to calculate reservoir ages directly from $F$ values. A caveat must be kept in mind for samples that formed in $\mathrm{AD} 1950$. The definition of $F$ assigns the value $F=1.0$ for atmospheric samples in 1950. However, the measured atmospheric age for the Southern Hemisphere in 1950 is $164 \pm 13$ yr, which gives an $F$ value of 0.9798 (McCormac et al. 2004). This discrepancy arises because the activity of the primary standard for AMS (oxalic acid) was chosen to reflect a pre-industrial $F$ value, not the actual 1950 value (Olsson 1970).

Coral ${ }^{14} \mathrm{C}$ results are usually quoted in $\Delta^{14} \mathrm{C}$ units, using the conventions discussed by Stuiver and Polach (1977). This is the age-corrected proportional difference in the ${ }^{14} \mathrm{C}$ content of a sample, compared to the 1950 atmosphere:

$$
\Delta^{14} \mathrm{C}=\left(F e^{\lambda(1950-x)}-1\right) \times 1000 \%
$$

where $\lambda=1 / 8267$ is the decay constant for a 5730 -yr half-life, and $x$ is the calendar age of the sample BP. The quantities $R$ and $\Delta^{14} \mathrm{C}$ can both be used to express differences between the ${ }^{14} \mathrm{C}$ content of the ocean and atmosphere. The 2 quantities are subtly and distinctly different, because $R$ compares the contemporary marine ${ }^{14} \mathrm{C}$ value with a contemporary atmospheric ${ }^{14} \mathrm{C}$ value; while $\Delta{ }^{14} \mathrm{C}$ compares the age-corrected contemporary marine ${ }^{14} \mathrm{C}$ value with the 1950 atmospheric value, as defined by the oxalic acid standard. We can solve Equation 5, for $F_{a t m}$ and $F_{\text {mar }}$ and substitute into Equation 4 to get the relationship between $R$ and $\Delta{ }^{14} \mathrm{C}$ :

$$
R=8033 \ln \left(\frac{\frac{\Delta^{14} \mathrm{C}_{a t m}}{1000}+1}{\frac{\Delta^{14} \mathrm{C}_{\text {mar }}}{1000}+1}\right)
$$

where $\Delta^{14} \mathrm{C}_{a t m}$ and $\Delta{ }^{14} \mathrm{C}_{\text {mar }}$ are contemporary atmospheric and marine values. As is the case for Equation 4, some care must be exercised when applying this equation to samples from 1950. According to the oxalic acid standard, the $\Delta^{14} \mathrm{C}_{a t m}$ at 1950 is zero; however, the actual Southern Hemisphere atmospheric value is $-20.2 \pm 1.6 \%$ (McCormac et al. 2004).

Since most coral papers report their findings as $\Delta^{14} \mathrm{C}$ values, we include the formula to compute the 1 standard deviation uncertainty $(d R)$ for Equation 6, which is:

$$
d R=\left\{\left[\frac{8033}{\left(\Delta^{14} \mathrm{C}_{a t m} / 1000\right)+1}\right]^{2}\left(\frac{d \Delta^{14} \mathrm{C}_{a t m}}{1000}\right)^{2}+\left[\frac{8033}{\left(\Delta^{14} \mathrm{C}_{m a r} / 1000\right)+1}\right]^{2}\left(\frac{d \Delta^{14} \mathrm{C}_{m a r}}{1000}\right)^{2}\right\}^{\frac{1}{2}}
$$

where $d \Delta{ }^{14} \mathrm{C}_{a t m}$ and $d \Delta{ }^{14} \mathrm{C}_{\text {mar }}$ are the 1 standard deviation uncertainties in these values. Some of the published data discussed below was reported using $\Delta^{14} \mathrm{C}$ values that were not age-corrected. This introduces a negligible error when comparing results from 1950. The difference between uncorrected and corrected $\Delta{ }^{14} \mathrm{C}$ values at 1950 is zero, with a maximum difference of $<0.6 \%$ between 1945 and 1955. 


\section{RESULTS}

The results for the 4 new coral records are given in Table 1 and shown in Figure 3. Quoted reservoir ages were calculated by subtracting Southern Hemisphere atmospheric values from tree-ring measurements compiled by McCormac et al. (2004) for the period 1940 to 1950. From 1951 to 1955, averaged tree-ring values from Tasmania (Hua et al. 2000) and Armidale, Australia (Hua et al. 2003) were used. Average reservoir values were computed using weighted means that included all of the measurements for each site. The external variance of these values was used to determine the uncertainty for a given site.

Table 1 Fraction modern carbon $(F)$ values, $\Delta^{14} \mathrm{C}$ values, reservoir ages, and $\delta^{13} \mathrm{C}$ values for modern corals: a. Marquesas Islands; b. Espiritu Santo Island, Vanuatu; c. Rabaul, Papua New Guinea; d. Ovahe, Easter Island. Uncertainties are $1 \sigma$.

\begin{tabular}{|c|c|c|c|c|c|c|}
\hline Sample ID & $\begin{array}{l}\text { Calibrated } \\
\text { age }\end{array}$ & $F$ & $\begin{array}{l}{ }^{14} \mathrm{C} \text { age } \\
\text { BP }\end{array}$ & $\Delta^{14} \mathrm{C}$ & $\begin{array}{l}\text { Reservoir } \\
\text { age }(R)^{\mathrm{a}}\end{array}$ & $\delta^{13} \mathrm{C}^{\mathrm{b}}$ \\
\hline \multicolumn{7}{|c|}{ a. Marquesas Islands $(n=26)$} \\
\hline AA50760 & 1955.5 & $0.9451 \pm 0.0046$ & $453 \pm 38$ & $-55.5 \pm 4.9$ & $297 \pm 41$ & -1.8 \\
\hline AA50761 & 1955.0 & $0.9300 \pm 0.0046$ & $583 \pm 39$ & $-70.6 \pm 4.9$ & $427 \pm 42$ & -1.1 \\
\hline AA50762 & 1954.5 & $0.9318 \pm 0.0065$ & $568 \pm 55$ & $-68.7 \pm 7.0$ & $412 \pm 57$ & -0.6 \\
\hline AA50763 & 1954.2 & $0.9363 \pm 0.0048$ & $528 \pm 41$ & $-64.2 \pm 5.1$ & $372 \pm 44$ & -0.6 \\
\hline AA50764 & 1953.5 & $0.9447 \pm 0.0045$ & $457 \pm 38$ & $-55.7 \pm 4.8$ & $301 \pm 41$ & -0.8 \\
\hline AA50765 & 1952.8 & $0.9280 \pm 0.0045$ & $601 \pm 38$ & $-72.3 \pm 4.9$ & $445 \pm 41$ & -0.8 \\
\hline AA50766 & 1952.4 & $0.9375 \pm 0.0042$ & $518 \pm 35$ & $-62.8 \pm 4.5$ & $354 \pm 37$ & -0.6 \\
\hline AA50767 & 1951.8 & $0.9370 \pm 0.0043$ & $523 \pm 36$ & $-63.2 \pm 4.6$ & $359 \pm 38$ & -1.0 \\
\hline AA50768 & 1951.3 & $0.9330 \pm 0.0042$ & $557 \pm 35$ & $-67.1 \pm 4.5$ & $393 \pm 37$ & -0.9 \\
\hline AA50769 & 1950.8 & $0.9375 \pm 0.0043$ & $518 \pm 36$ & $-62.6 \pm 4.6$ & $354 \pm 38$ & -0.9 \\
\hline AA51711 & 1950.3 & $0.9302 \pm 0.0047$ & $581 \pm 39$ & $-69.8 \pm 5.1$ & $417 \pm 41$ & 0.0 \\
\hline AA51712 & 1949.8 & $0.9429 \pm 0.0043$ & $472 \pm 35$ & $-57.1 \pm 4.6$ & $308 \pm 37$ & -0.7 \\
\hline AA51713 & 1949.3 & $0.9340 \pm 0.0042$ & $548 \pm 35$ & $-65.9 \pm 4.5$ & $384 \pm 37$ & 0.0 \\
\hline AA51714 & 1948.8 & $0.9363 \pm 0.0041$ & $529 \pm 35$ & $-63.6 \pm 4.4$ & $365 \pm 37$ & 0.0 \\
\hline AA51715 & 1948.3 & $0.9466 \pm 0.0042$ & $441 \pm 35$ & $-53.2 \pm 4.4$ & $277 \pm 37$ & -1.0 \\
\hline AA51716 & 1947.8 & $0.9284 \pm 0.0056$ & $597 \pm 47$ & $-71.4 \pm 6.0$ & $433 \pm 49$ & -0.6 \\
\hline AA51717 & 1947.3 & $0.9389 \pm 0.0042$ & $506 \pm 35$ & $-60.8 \pm 4.5$ & $350 \pm 36$ & -1.0 \\
\hline AA51718 & 1946.3 & $0.9414 \pm 0.0042$ & $485 \pm 35$ & $-58.2 \pm 4.5$ & $329 \pm 36$ & -0.9 \\
\hline AA51719 & 1945.8 & $0.9291 \pm 0.0044$ & $591 \pm 37$ & $-70.4 \pm 4.7$ & $435 \pm 38$ & -1.2 \\
\hline AA51720 & 1945.3 & $0.9379 \pm 0.0042$ & $515 \pm 35$ & $-61.6 \pm 4.5$ & $359 \pm 36$ & -0.9 \\
\hline AA51721 & 1944.9 & $0.9388 \pm 0.0030$ & $511 \pm 37$ & $-60.6 \pm 3.2$ & $355 \pm 38$ & -0.8 \\
\hline AA51722 & 1944.4 & $0.9403 \pm 0.0042$ & $494 \pm 35$ & $-59.1 \pm 4.5$ & $338 \pm 36$ & -0.9 \\
\hline AA51723 & 1943.9 & $0.9429 \pm 0.0042$ & $473 \pm 35$ & $-56.4 \pm 4.5$ & $317 \pm 36$ & -1.0 \\
\hline AA51724 & 1943.4 & $0.9461 \pm 0.0041$ & $445 \pm 34$ & $-53.2 \pm 4.3$ & $289 \pm 35$ & -0.6 \\
\hline AA51725 & 1943.0 & $0.9370 \pm 0.0042$ & $523 \pm 35$ & $-62.2 \pm 4.5$ & $367 \pm 36$ & -0.5 \\
\hline AA51726 & 1942.5 & $0.9401 \pm 0.0046$ & $496 \pm 38$ & $-59.0 \pm 4.9$ & $342 \pm 39$ & -0.7 \\
\hline \multicolumn{7}{|c|}{ Average reservoir age $=356.0 \pm 9.0$} \\
\hline \multicolumn{7}{|c|}{ b. Santo Island, Vanuatu $(n=35)$} \\
\hline AA18811 & 1950.0 & $0.9301 \pm 0.0039$ & $582 \pm 34$ & $-69.9 \pm 4.2$ & $418 \pm 36$ & -0.4 \\
\hline AA15741 & 1950.2 & $0.9457 \pm 0.0058$ & $448 \pm 49$ & $-54.3 \pm 6.1$ & $284 \pm 51$ & -1.0 \\
\hline AA14811 & 1950.3 & $0.9401 \pm 0.0051$ & $496 \pm 44$ & $-59.9 \pm 5.4$ & $332 \pm 46$ & $(-0.7)$ \\
\hline AA18812 & 1950.6 & $0.9344 \pm 0.0042$ & $545 \pm 36$ & $-65.7 \pm 4.5$ & $381 \pm 38$ & -0.7 \\
\hline AA14812 & 1950.9 & $0.9371 \pm 0.0050$ & $522 \pm 43$ & $-63.0 \pm 5.3$ & $358 \pm 45$ & $(-0.7)$ \\
\hline AA18809 & 1951.0 & $0.9375 \pm 0.0038$ & $518 \pm 33$ & $-62.6 \pm 4.1$ & $354 \pm 35$ & -0.6 \\
\hline AA15739 & 1951.2 & $0.9337 \pm 0.0052$ & $551 \pm 45$ & $-66.4 \pm 5.6$ & $387 \pm 47$ & -0.5 \\
\hline
\end{tabular}


Table 1 Fraction modern carbon $(F)$ values, $\Delta^{14} \mathrm{C}$ values, reservoir ages, and $\delta^{13} \mathrm{C}$ values for modern corals: a. Marquesas Islands; b. Espiritu Santo Island, Vanuatu; c. Rabaul, Papua New Guinea; d. Ovahe, Easter Island. Uncertainties are $1 \sigma$. (Continued)

\begin{tabular}{|c|c|c|c|c|c|c|}
\hline Sample ID & $\begin{array}{l}\text { Calibrated } \\
\text { age }\end{array}$ & $F$ & $\begin{array}{l}{ }^{14} \mathrm{C} \text { age } \\
\text { BP }\end{array}$ & $\Delta{ }^{14} \mathrm{C}$ & $\begin{array}{l}\text { Reservoir } \\
\text { age }(R)^{\mathrm{a}}\end{array}$ & $\delta^{13} \mathrm{C}^{\mathrm{b}}$ \\
\hline AA14809 & 1951.3 & $0.9402 \pm 0.0053$ & $495 \pm 45$ & $-60.0 \pm 5.6$ & $331 \pm 47$ & $(-0.6)$ \\
\hline AA 18810 & & $0.9412 \pm 0.0038$ & $487 \pm 32$ & $-59.0 \pm 4.0$ & & -0.7 \\
\hline AA15742 & 1951.8 & $9467 \pm 0.0070$ & $440 \pm 59$ & & $276 \pm 61$ & -0.6 \\
\hline AA 15740 & 1951.8 & $9466 \pm 0.0056$ & $441 \pm 48$ & $-53.6 \pm 5.9$ & $277 \pm 49$ & -0.9 \\
\hline AA14810 & 1951.9 & $.9432 \pm 0.0052$ & $470 \pm 44$ & $-57.0 \pm 5.5$ & & $(-0.6)$ \\
\hline AA18807 & 1952.0 & $0.9377 \pm 0.0061$ & $517 \pm 52$ & $-62.5 \pm 6.5$ & & -0.6 \\
\hline AA 15737 & & 0.0058 & $438 \pm 49$ & & & \\
\hline & & & $485 \pm 44$ & & & $(-0.6)$ \\
\hline AA18808 & & & $617 \pm 52$ & & & \\
\hline AA15738 & 1952.8 & $0.9442 \pm 0.0057$ & $461 \pm 48$ & $-56.1 \pm 6.0$ & & -0.6 \\
\hline & & & $574 \pm$ & & & -0.3 \\
\hline & & & $411 \pm$ & & & \\
\hline & & & $423=$ & & & \\
\hline & & & $531 \pm 54$ & & & -0.4 \\
\hline & & & $425 \pm 53$ & & & -0.5 \\
\hline & & & 474 & & & \\
\hline & & & 57 & & & -0.3 \\
\hline & & & $463=$ & & & -0.7 \\
\hline & & & $394 \pm$ & & & \\
\hline & & & & & & \\
\hline & & & 48 & & & -0 \\
\hline & & & & & & $(-0.5)$ \\
\hline & & 66 & $609 \pm$ & $.6 \pm 7.1$ & & -0.4 \\
\hline & & & & & & \\
\hline & & & & & & $(-0.8)$ \\
\hline & & & 500 & & & -0.8 \\
\hline & & & $428=$ & & & -1.2 \\
\hline AA14802 & 1955.9 & $0.9596 \pm 0.0062$ & $331 \pm 52$ & & & $(-0.8)$ \\
\hline Average res & rvoir age $=$ & $32 \pm 10$ & & & & \\
\hline c. Rabaul, & apua New & uinea $(n=43)$ & & & & \\
\hline & & & $416 \pm 27$ & & & -1.5 \\
\hline & & & & & & -1.8 \\
\hline & & & & & & -2 \\
\hline AA65642 & & & $440 \pm 40$ & $-53.9 \pm 5.0$ & $284 \pm 43$ & -1.7 \\
\hline & & & $463 \pm 34$ & $-56.5 \pm 4.2$ & $307 \pm 38$ & -2.1 \\
\hline & & & & & & $(-1.4)$ \\
\hline & & & & & & \\
\hline & & & $532=$ & 5.0 & $376=$ & $(-1$. \\
\hline & & & $454 \pm 24$ & & & $(-1.4)$ \\
\hline AA65648 & 1953.5 & $0.9377 \pm 0.0039$ & $517 \pm 33$ & $-62.7 \pm 4.2$ & $361 \pm 37$ & $(-1.4)$ \\
\hline & & & & & & \\
\hline & & & $452 \pm 33$ & & & \\
\hline & & & $520 \pm 33$ & $-63.0 \pm 4.2$ & $364 \pm 37$ & $(-1.4)$ \\
\hline & & $0.9470 \pm 0.0040$ & $438 \pm 34$ & $-53.3 \pm 4.2$ & $274 \pm 36$ & $(-1.4)$ \\
\hline AA65653 & 1952.2 & $0.9434 \pm 0.0052$ & $468 \pm 44$ & $-56.9 \pm 5.5$ & $304 \pm 46$ & $(-1.4)$ \\
\hline
\end{tabular}


Table 1 Fraction modern carbon $(F)$ values, $\Delta^{14} \mathrm{C}$ values, reservoir ages, and $\delta^{13} \mathrm{C}$ values for modern corals: a. Marquesas Islands; b. Espiritu Santo Island, Vanuatu; c. Rabaul, Papua New Guinea; d. Ovahe, Easter Island. Uncertainties are $1 \sigma$. (Continued)

\begin{tabular}{|c|c|c|c|c|c|c|}
\hline Sample ID & $\begin{array}{l}\text { Calibrated } \\
\text { age }\end{array}$ & $F$ & $\begin{array}{l}{ }^{14} \mathrm{C} \text { age } \\
\mathrm{BP}\end{array}$ & $\Delta{ }^{14} \mathrm{C}$ & $\begin{array}{l}\text { Reservoir } \\
\text { age }(R)^{\mathrm{a}}\end{array}$ & $\delta^{13} \mathrm{C}^{\mathrm{b}}$ \\
\hline AA65654 & 1952.0 & $0.9315 \pm 0.0046$ & $570 \pm 40$ & $-68.8 \pm 4.9$ & $406 \pm 42$ & $(-1.4)$ \\
\hline AA65655 & 1951.8 & $0.9397 \pm 0.0039$ & $500 \pm 33$ & $-60.5 \pm 4.2$ & $336 \pm 36$ & -0.9 \\
\hline AA65656 & 1951.5 & $0.9420 \pm 0.0039$ & $480 \pm 33$ & $-58.2 \pm 4.1$ & $316 \pm 36$ & -2.4 \\
\hline AA65657 & 1951.2 & $0.9440 \pm 0.0049$ & $463 \pm 42$ & $-56.1 \pm 5.2$ & $299 \pm 44$ & -0.6 \\
\hline AA65658 & 1951.0 & $0.9449 \pm 0.0048$ & $455 \pm 41$ & $-55.2 \pm 5.1$ & $291 \pm 43$ & -0.7 \\
\hline AA65659 & 1950.8 & $0.9375 \pm 0.0039$ & $518 \pm 33$ & $-62.6 \pm 4.2$ & $354 \pm 36$ & -1.7 \\
\hline AA65660 & 1950.5 & $0.9411 \pm 0.0057$ & $488 \pm 49$ & $-59.0 \pm 6.1$ & $324 \pm 50$ & -1.7 \\
\hline AA65662 & 1950.0 & $0.9438 \pm 0.0046$ & $465 \pm 39$ & $-56.2 \pm 4.9$ & $301 \pm 41$ & -2.7 \\
\hline AA65663 & 1949.8 & $0.9394 \pm 0.0045$ & $502 \pm 38$ & $-60.6 \pm 4.8$ & $338 \pm 41$ & -2.5 \\
\hline AA65664 & 1949.5 & $0.9378 \pm 0.0033$ & $516 \pm 28$ & $-62.1 \pm 3.5$ & $352 \pm 31$ & -1.5 \\
\hline AA65665 & 1949.2 & $0.9423 \pm 0.0034$ & $477 \pm 29$ & $-57.6 \pm 3.6$ & $313 \pm 32$ & -1.9 \\
\hline AA65666 & 1949.0 & $0.9407 \pm 0.0032$ & $491 \pm 27$ & $-59.2 \pm 3.4$ & $327 \pm 30$ & -2.7 \\
\hline AA65667 & 1948.8 & $0.9383 \pm 0.0051$ & $512 \pm 44$ & $-61.6 \pm 5.4$ & $348 \pm 46$ & -1.5 \\
\hline AA65668 & 1948.5 & $0.9423 \pm 0.0046$ & $477 \pm 39$ & $-57.5 \pm 4.9$ & $313 \pm 41$ & -1.5 \\
\hline AA65669 & 1948.2 & $0.9446 \pm 0.0033$ & $458 \pm 28$ & $-55.2 \pm 3.5$ & $294 \pm 31$ & -2.1 \\
\hline AA65670 & 1948.0 & $0.9403 \pm 0.0034$ & $494 \pm 29$ & $-59.5 \pm 3.6$ & $330 \pm 32$ & -2.4 \\
\hline AA65671 & 1947.8 & $0.9440 \pm 0.0033$ & $463 \pm 28$ & $-55.7 \pm 3.5$ & $299 \pm 31$ & -1.0 \\
\hline AA65672 & 1947.5 & $0.9337 \pm 0.0040$ & $551 \pm 34$ & $-66.0 \pm 4.3$ & $395 \pm 35$ & -1.0 \\
\hline AA65673 & 1947.2 & $0.9556 \pm 0.0066$ & $365 \pm 55$ & $-44.1 \pm 6.9$ & $209 \pm 56$ & -2.3 \\
\hline AA65674 & 1947.0 & $0.9359 \pm 0.0042$ & $532 \pm 36$ & $-63.8 \pm 4.5$ & $376 \pm 37$ & -0.8 \\
\hline AA65675 & 1946.8 & $0.9410 \pm 0.0047$ & $489 \pm 40$ & $-58.6 \pm 5.0$ & $333 \pm 41$ & -0.7 \\
\hline AA65676 & 1946.5 & $0.9556 \pm 0.0066$ & $365 \pm 55$ & $-44.0 \pm 6.9$ & $209 \pm 56$ & -1.5 \\
\hline AA65677 & 1946.2 & $0.9399 \pm 0.0030$ & $498 \pm 26$ & $-59.7 \pm 3.2$ & $342 \pm 27$ & -0.6 \\
\hline AA65678 & 1946.0 & $0.9400 \pm 0.0047$ & $497 \pm 40$ & $-59.5 \pm 5.0$ & $341 \pm 41$ & -0.6 \\
\hline AA65679 & 1945.8 & $0.9349 \pm 0.0042$ & $541 \pm 36$ & $-64.6 \pm 4.5$ & $385 \pm 37$ & -0.3 \\
\hline AA65680 & 1945.5 & $0.9434 \pm 0.0042$ & $468 \pm 36$ & $-56.1 \pm 4.4$ & $312 \pm 37$ & -0.7 \\
\hline AA65681 & 1945.2 & $0.9512 \pm 0.0065$ & $402 \pm 55$ & $-48.3 \pm 6.8$ & $246 \pm 55$ & -0.5 \\
\hline AA65682 & 1945.0 & $0.9361 \pm 0.0048$ & $530 \pm 41$ & $-63.3 \pm 5.1$ & $374 \pm 42$ & -0.4 \\
\hline \multicolumn{7}{|c|}{ Average reservoir age $=322.5 \pm 6.3$} \\
\hline \multicolumn{7}{|c|}{ d. Ovahe, Easter Island, Chile $(n=9)$} \\
\hline AA40626 & 1952.2 & $0.9520 \pm 0.0047$ & $395 \pm 40$ & $-48.3 \pm 4.9$ & $231 \pm 42$ & -2.9 \\
\hline AA40562 & 1952.6 & $0.9516 \pm 0.0047$ & $399 \pm 40$ & $-48.7 \pm 4.9$ & $243 \pm 43$ & -3.0 \\
\hline AA42611 & 1953.1 & $0.9501 \pm 0.0043$ & $411 \pm 36$ & $-50.3 \pm 4.5$ & $255 \pm 40$ & -2.9 \\
\hline AA42285 & 1953.6 & $0.9519 \pm 0.0043$ & $396 \pm 36$ & $-48.5 \pm 4.5$ & $240 \pm 40$ & -2.8 \\
\hline AA42278 & 1954.2 & $0.9548 \pm 0.0044$ & $372 \pm 37$ & $-45.7 \pm 4.6$ & $216 \pm 40$ & -2.5 \\
\hline AA42613 & 1955.0 & $0.9431 \pm 0.0043$ & $471 \pm 37$ & $-57.5 \pm 4.6$ & $315 \pm 40$ & -2.3 \\
\hline AA42287 & 1955.4 & $0.9492 \pm 0.0043$ & $419 \pm 36$ & $-51.4 \pm 4.5$ & $263 \pm 40$ & -2.1 \\
\hline AA41067 & 1955.7 & $0.9572 \pm 0.0055$ & $351 \pm 46$ & $-43.5 \pm 5.7$ & $195 \pm 49$ & -2.6 \\
\hline AA42280 & 1955.8 & $0.9499 \pm 0.0043$ & $413 \pm 36$ & $-50.8 \pm 4.5$ & $257 \pm 40$ & -2.8 \\
\hline \multicolumn{7}{|c|}{ Average reservoir age $=248 \pm 11$} \\
\hline
\end{tabular}

${ }^{a}$ Reservoir ages are calculated using data from SHCal data set (McCormac et al. 2004) for 1940 to 1950, and average treering values from Tasmania (Hua et al. 2000) and Armidale, Australia (Hua et al. 2003) for 1951 to 1955.

${ }^{b}$ Values in parentheses are estimated. 

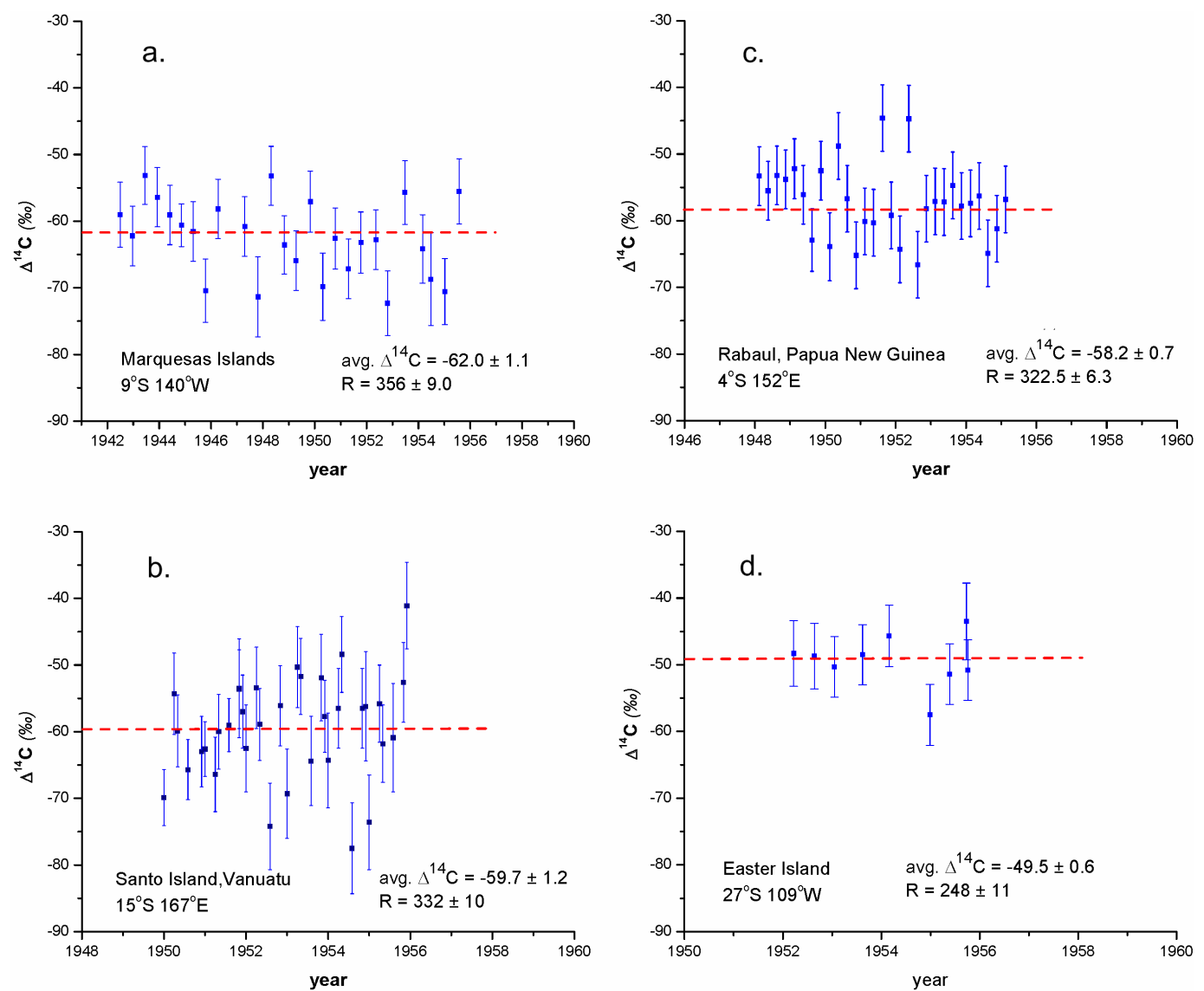

Figure 3 South Pacific coral $\Delta^{14} \mathrm{C}$ time series for the 4 sites studied: a) Marquesas Islands; b) Espiritu Santo Island, Vanuatu; c) Rabaul, Papua New Guinea; d) Ovahe, Easter Island. Reservoir ages $(R)$ are taken as the weighted average of the measurements. Uncertainties are $1 \sigma$, taken as the external variance from the sample distribution.

All of the reservoir values are plotted together in Figure 3 at the same scale. The Marquesas Islands site has the oldest reservoir age $\left(356.0 \pm 9.0{ }^{14} \mathrm{C}\right.$ yr). Espiritu Santo $\left(332 \pm 10{ }^{14} \mathrm{C}\right.$ yr $)$ and Rabaul $\left(322.5 \pm 6.3{ }^{14} \mathrm{C} \mathrm{yr}\right)$ are slightly younger, and statistically indistinguishable from one another. Seasonal variations in $\Delta^{14} \mathrm{C}$ are relatively small at the Marquesas Islands site, with a total range of less than 20\%o. They are slightly larger at Rabaul, and substantially larger ( 40\%) at Espiritu Santo. This suggests that the seasonal change in surface currents at Vanuatu involves surface waters carrying distinctly different ${ }^{14} \mathrm{C}$ signatures. The data are consistent with progressively younger ages from east to west, parallel to the SEC flow path.

The average reservoir age for Easter Island $\left(248 \pm 11{ }^{14} \mathrm{C}\right.$ yr $)$ stands apart from the others and reflects its fundamentally different oceanographic setting, in the central portion of the South Pacific Subtropical Gyre. The small amount of data for Easter Island has a very tight range, less than $15 \%$, consistent with uniform low-velocity surface currents at this site (Figure 3).

\section{DISCUSSION}

The coral-based ${ }^{14} \mathrm{C}$ reservoir ages for the 1940s and 1950s reported here show striking consistency with 9 other published studies from the South Pacific (Table 2). The region bound by the Marquesas 
Islands, Fiji, and Nauru has a weighted average reservoir age of $361.6 \pm 8.2{ }^{14} \mathrm{C}$ yr $(2 \sigma)$. To the south and west, Vanuatu, the Solomon Islands, and Papua New Guinea have a weighted mean average of $322.1 \pm 8.6{ }^{14} \mathrm{C} \mathrm{yr}(2 \sigma)$. The 2 regions taken together cover about 12 million $\mathrm{km}^{2}$. The largest reservoir ages are from the East Equatorial Pacific (Druffel 1981), centered around the Galapagos archipelago, at $450 \pm 16{ }^{14} \mathrm{C}$ yr $(2 \sigma)$. These data reflect an equatorial zone of reservoir ages that decrease westward, with a gradient that follows the surface currents of the SEC (Figure 4). This trend is a manifestation of the Ekman-driven upwelling of ${ }^{14} \mathrm{C}$-depleted waters along the coast of Peru (Toggweiler et al. 1991). These ${ }^{14} \mathrm{C}$-depleted waters propagate westward within the broad SEC system, driven by the easterlies. During westward transport in the SEC, reservoir ages are likely to be reduced in response to continual $\mathrm{CO}_{2}$ exchange across the air-sea interface. At the same time, upwelling is expected to be attenuated as the thermocline deepens towards the west.

Table 2 Summary of South Pacific reservoir ages. Reservoir ages are calculated in the same manner as the study samples, using published data for South Pacific corals, and 1 sponge record from Vanuatu. Tabulated values were used when available, and interpolated values published in graphic form were used for the remainder. Uncertainties are $1 \sigma$.

\begin{tabular}{|c|c|c|c|}
\hline Location & Time range & $\begin{array}{l}\text { Average } \\
\text { reservoir } \\
\text { age }\left({ }^{14} \mathrm{C} \text { yr }\right)\end{array}$ & Source \\
\hline a.Tropical sites & & & \\
\hline $\begin{array}{l}\text { Galapagos Islands } \\
\left(0.5^{\circ} \mathrm{S}, 91.23^{\circ} \mathrm{W}\right)\end{array}$ & 1945-1954 & $450 \pm 8$ & Druffel 1981 \\
\hline $\begin{array}{l}\text { Marquesas Islands } \\
\left(9^{\circ} \mathrm{S}, 140^{\circ} \mathrm{W}\right)\end{array}$ & $1942-1955$ & $356 \pm 9$ & this study \\
\hline $\begin{array}{l}\text { Fiji } \\
\left(18^{\circ} \mathrm{S}, 179^{\circ} \mathrm{E}\right)\end{array}$ & $1945-1955$ & $361 \pm 13$ & Toggweiler et al. 1991 \\
\hline $\begin{array}{l}\text { Nauru } \\
\left(0^{\circ} 30^{\prime} \mathrm{S}, 167^{\circ} \mathrm{E}\right)\end{array}$ & $1947-1957$ & $369 \pm 10$ & Guilderson et al. 1998 \\
\hline $\begin{array}{l}\text { Vanuatu } \\
\left(13.8^{\circ} \mathrm{S}, 167.5^{\circ} \mathrm{E}\right)\end{array}$ & $1953-1955$ & $345 \pm 21$ & $\begin{array}{l}\text { Fallon et al. } 2003 \\
\text { (sponge record) }\end{array}$ \\
\hline $\begin{array}{l}\text { Vanuatu } \\
\left(15^{\circ} \mathrm{S}, 167^{\circ} \mathrm{E}\right)\end{array}$ & $1950-1955$ & $332 \pm 10$ & this study \\
\hline $\begin{array}{l}\text { Solomon Islands } \\
\left(9^{\circ} \mathrm{S}, 161^{\circ} \mathrm{E}\right)\end{array}$ & $1945-1955$ & $323 \pm 11$ & Schmidt et al. 2004 \\
\hline $\begin{array}{l}\text { Solomon Islands } \\
\left(9^{\circ} \mathrm{S}, 159^{\circ} 40^{\prime} \mathrm{E}\right)\end{array}$ & $1943-1957$ & $309 \pm 8.9$ & Guilderson et al. 2004 \\
\hline $\begin{array}{l}\text { Rabaul, PNG } \\
\left(4^{\circ} \mathrm{S}, 152^{\circ} \mathrm{E}\right)\end{array}$ & $1945-1955$ & $322.5 \pm 6.3$ & this study \\
\hline b. Subtropical sites & & & \\
\hline $\begin{array}{l}\text { Easter Island, Chile } \\
\left(27^{\circ} \mathrm{S}, 109^{\circ} \mathrm{W}\right)\end{array}$ & $1952-1955$ & $248 \pm 11$ & this study \\
\hline $\begin{array}{l}\text { Rarotonga, Cook Islands } \\
\left(21^{\circ} \mathrm{S}, 160^{\circ} \mathrm{W}\right)\end{array}$ & $1950-1957$ & $275.0 \pm 9.2$ & Guilderson et al. 2000b \\
\hline Abraham Reef, Australia & $1945-1955$ & $275 \pm 9$ & Druffel and Griffin 1993 \\
\hline Great Barrier Reef $\left(22^{\circ} \mathrm{S}, 153^{\circ} \mathrm{E}\right)$ & & & Druffel and Griffin 1999 \\
\hline $\begin{array}{l}\text { Heron Island, Australia } \\
\text { Great Barrier Reef }\left(23^{\circ} \mathrm{S}, 152^{\circ} \mathrm{E}\right)\end{array}$ & $1950-1955$ & $254 \pm 17$ & Druffel and Griffin 1995 \\
\hline
\end{tabular}


The reservoir age gradient also decreases towards the subtropics because of the influence of the subtropical gyre. This drives strong surface convergence in the mixed layer, depressing the thermocline beyond the reach of wind-driven mixing. Easter Island is located near the latitudinal center of convergence for the subtropics, and is part of a belt that extends westward across the South Pacific. The dynamics of this zone produces a homogeneous reservoir age for all of the sites within it. The weighted average reservoir age for Easter Island, Rarotonga, and the Great Barrier Reef is $266.8 \pm$ $13.8{ }^{14} \mathrm{C}$ yr $(2 \sigma)$. Figure 4 summarizes the marine reservoir picture for the South Pacific between 1945 and 1955 using all available ${ }^{14} \mathrm{C}$ records.

An important corollary to our overview of modern reservoir ages is that composite coral-based reservoir age records can be combined to document and understand temporal reservoir age variability in the past. Paterne et al. (2004) calculated numerous reservoir ages in fossil South Pacific corals from the Marquesas Islands and Tahiti by establishing calendar ages using U/Th dating, and coupling these results with ${ }^{14} \mathrm{C}$ measurements. They estimated a rather uniform marine reservoir age for the central Pacific of $\sim 400{ }^{14} \mathrm{C}$ yr up to $9 \mathrm{kyr} \mathrm{BP}$. From 9 to $11 \mathrm{kyr} \mathrm{BP}$, their results showed a reservoir age for the Marquesas Islands of $390 \pm 60{ }^{14} \mathrm{C}$ yr $(2 \sigma)$, and $280 \pm 50{ }^{14} \mathrm{C}$ yr $(2 \sigma)$ for Tahiti. These are the same as our modern values within errors, and suggest that no significant ocean circulation variability occurred during this time. McGregor et al. (2008) used a similar approach to measure paleo-reservoir ages in Holocene corals from Papua New Guinea. Their data showed a significant change in reservoir age in the Bismarck Sea between 7220 and 5850 BP, when reservoir ages fell to $\sim 180{ }^{14} \mathrm{C}$ yr. Between 5850 and 5420 , reservoir ages there increased to modern values. These authors suggested that the onset of El Niño activity accompanied a change in surface circulation during this period. The analytical approach of Paterne et al. (2004) and McGregor et al. (2008), combined with the high temporal resolution achieved with dating continuous growth bands, could, in principle, be used to produce high-resolution paleo-reservoir age records for much of the South Pacific - that is, to construct a firmly dated marine calibration curve from banded fossil corals, at least through the Holocene. The longest continuous Holocene coral records available today are a 367-yr record from the Galapagos (Druffel et al. 2007) and a 323-yr record from the Great Barrier Reef (Druffel and Griffin 1993). Fossil corals, collected from uplifted terraces or drilled from the subsurface, could extend these records into the past.

Two examples of such fossil corals are a Diploastrea heliopora that lived in Vanuatu between about 11.8 and $12.5 \mathrm{kyr}$ BP (Burr et al. 1998) and a Goniastrea favulus that lived in PNG from 13.0 to 13.1 kyr BP (Burr et al. 2004). The Goniastrea record lies beyond the limit of the existing ${ }^{14} \mathrm{C}$ tree-ring chronology, but the Diploastrea ${ }^{14} \mathrm{C}$ record overlaps the existing tree-ring calibration between 11.8 and $12.4 \mathrm{kyr}$ BP. We use this record to construct the paleo-reservoir time series plot shown in Figure 5. This figure incorporates the ${ }^{14} \mathrm{C}$ data of Burr et al. (1998), and recalculated ${ }^{230} \mathrm{Th}$ ages with updated half-lives (Cheng et al. 2000). Reservoir ages were reconstructed by comparing the coral measurements with tree-ring data for the same period (Friedrich et al. 2004). Each data point shown in Figure 5 is a weighted average of annual ${ }^{14} \mathrm{C}$ coral measurements - using every year for each decade where available.

It is well known that the Younger Dryas was a time of extreme climate change with large fluctuations in deep ocean ventilation (Edwards et al. 1993). Our record indicates substantial reservoir age variability at this time, with a range of about $400{ }^{14} \mathrm{C}$ yr $\left(230-650{ }^{14} \mathrm{C}\right.$ yr). This range is considerably larger than that observed in modern pre-bomb corals. Such variability is consistent with major ocean ventilation changes linked to North Atlantic freshwater inputs, or possibly changes in ${ }^{14} \mathrm{C}$ produc- 


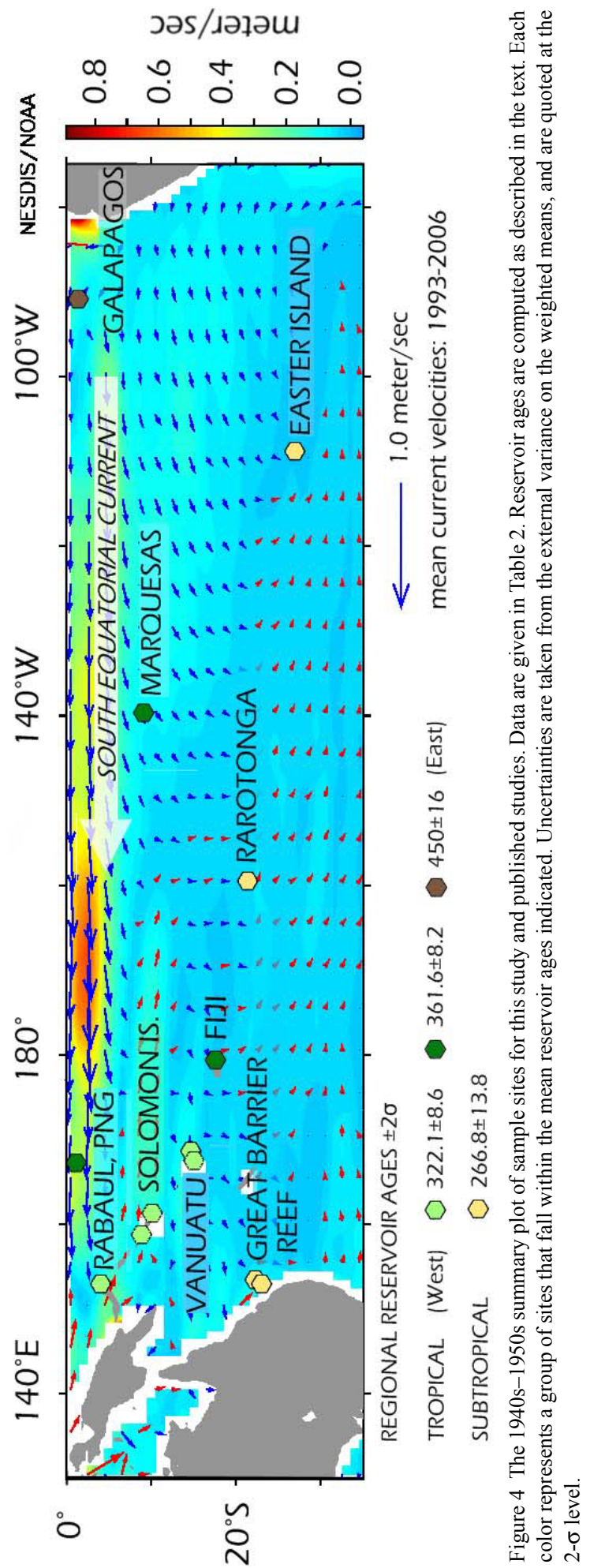




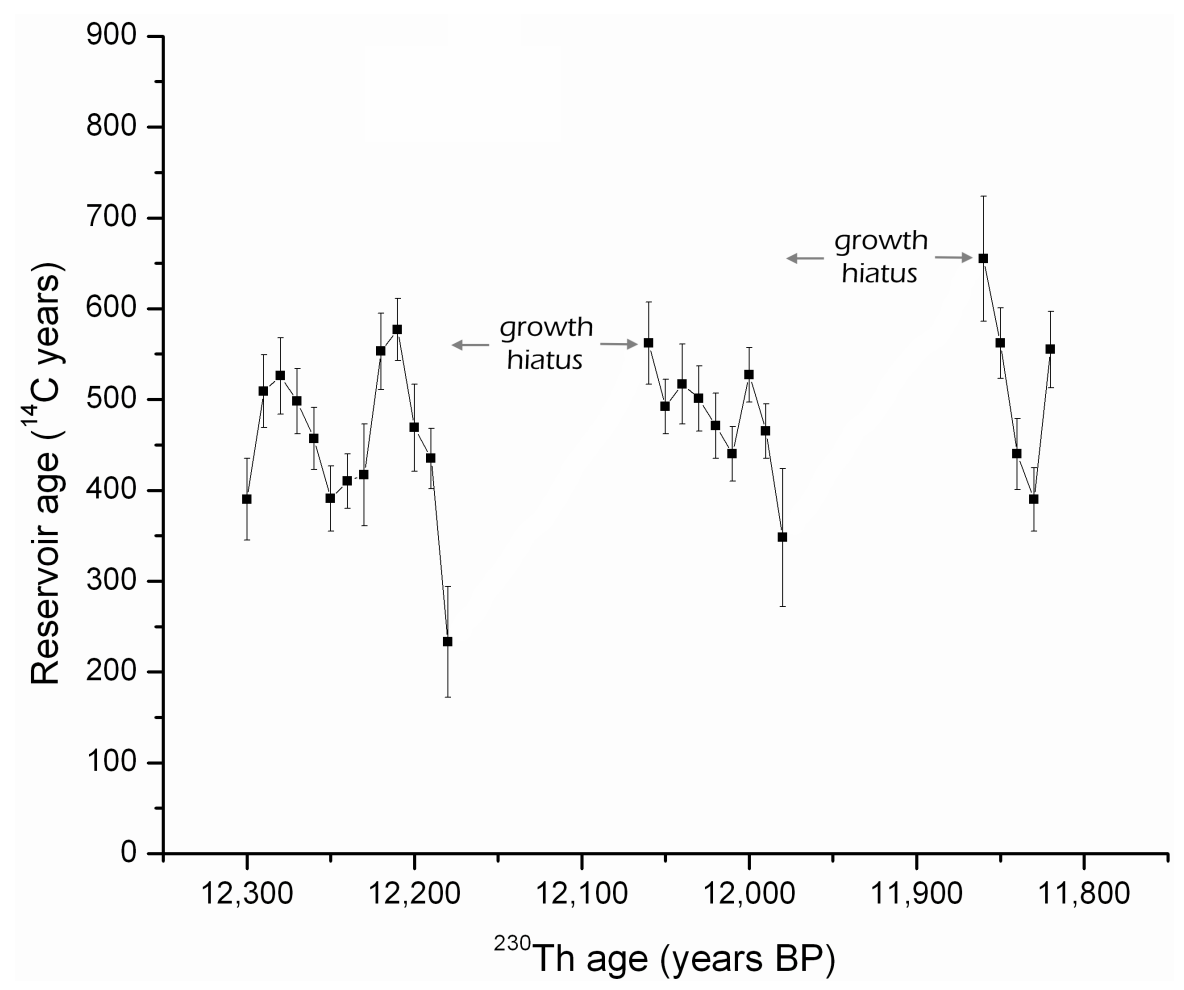

Figure 5 Plot of the surface ocean reservoir age at Vanuatu between 11.9 and $12.3 \mathrm{cal} \mathrm{kyr} \mathrm{BP.} \mathrm{Data}$ compiled from Burr et al. (1998) and Friedrich et al. (2004). The ${ }^{230} \mathrm{Th}$ ages from Burr et al. have been recalculated using the half-life values of Cheng et al. (2000). Uncertainties are $1 \sigma$.

tion rate at that time (Singarayer et al. 2008). An intriguing feature of our record are large reservoir age increases that just precede growth hiatuses, suggesting a concomitant decrease in water temperature (Figure 5). We know from trace element studies of this same coral that the average sea surface temperature (SST) at the time was $4.5^{\circ} \mathrm{C}$ cooler than today, and that this was accompanied by substantial SST variability (Corrège et al. 2004). It is also observed that the coral only recovered from the growth hiatus after the reservoir age dropped to lower values.

The maximum continuous single reservoir age increase $\left(\sim 300{ }^{14} \mathrm{C}\right.$ yr $)$ is larger than the maximum decrease observed in the record $\left(\sim 150{ }^{14} \mathrm{C} \mathrm{yr}\right)$, while the maximum rate of change in reservoir age is about the same in either direction $\left(\sim 100{ }^{14} \mathrm{C} \mathrm{yr} /\right.$ decade $)$.

Despite these large ${ }^{14} \mathrm{C}$ fluctuations, the weighted average reservoir age for the entire 500-yr period remained rather constant, at $476 \pm 26{ }^{14} \mathrm{C}$ yr $(2 \sigma)$. This is not a surprising result because once perturbed the system will seek to restore a steady state, as the ocean and atmosphere are tightly coupled, and $R$ values reflect the difference between the contemporary ocean and atmosphere. The paleo-reservoir age for the Younger Dryas is similar to the modern reservoir age value quoted in Burr et al. (1998) of $494 \pm 10{ }^{14} \mathrm{C} \mathrm{yr}$; however, that value was calculated with a 1950 reservoir age of zero, and should have been reduced by $164{ }^{14} \mathrm{C}$ yr, as discussed above. The corrected Younger Dryas average marine reservoir age is $\sim 150 \mathrm{yr}$ older than the reservoir age in modern times and more variable.

The Diploastrea record is a good example of the kind of temporal resolution possible with fossil corals. No other coral record from the Younger Dryas is available for comparison; however, Paterne et 
al. (2004) made similar measurements in 2 fossil corals from Marquesas that showed similar ${ }^{14} \mathrm{C}$ age variability. One of these was U/Th dated to $\sim 12 \mathrm{kyr} \mathrm{BP}$. The authors reported ${ }^{14} \mathrm{C}$ ages in this coral that implied a mean reservoir age of $\sim 750{ }^{14} \mathrm{C}$ yr with a reservoir age variability on the order of \pm 300 yr. A second coral was U/Th dated to $\sim 15 \mathrm{kyr} \mathrm{BP}$ and gave similar reservoir age variability. The authors suggested sudden and profound deep ocean ventilation, or possibly diagenetic alteration as the cause of the ${ }^{14} \mathrm{C}$ variability. Our findings from the Vanuatu Diploastrea record strongly favor enhanced ocean ventilation.

The picture of reservoir age variability reflected in the Diploastrea record is consistent with climate modeling using Younger Dryas $\Delta^{14} \mathrm{C}$ values (Singarayer et al. 2008). The Singarayer et al. model study concludes that atmospheric ${ }^{14} \mathrm{C}$ changes during the Younger Dryas were caused primarily by ocean circulation changes. They also found that changes in reservoir effect across the Younger Dryas chronozone were probably substantially different in the South Pacific and North Atlantic. Larger Atlantic basin reservoir effects are likely to have occurred because of their proximity to the center of North Atlantic ocean ventilation changes. Smaller and more homogeneous changes are likely to have occurred in the South Pacific. This is a characteristic that favors using Pacific data when inferring atmospheric ${ }^{14} \mathrm{C}$ values for the purpose of ${ }^{14} \mathrm{C}$ calibration. To conclude, we would like to note that although our findings do not identify the mechanisms that caused the observed South Pacific ${ }^{14} \mathrm{C}$ reservoir age fluctuations, they do place important constraints on the rate and magnitude of these changes.

\section{CONCLUSIONS}

Modern reservoir age values are very uniform over vast regions of the South Pacific. We have identified 3 homogeneous regions for the pre-bomb 1940s and 1950s, as follows: 1) Central Equatorial South Pacific $\left(361 \pm 8.2{ }^{14} \mathrm{C}\right.$ yr, $\left.2 \sigma\right)$; Western Equatorial South Pacific $\left(322.1 \pm 8.6{ }^{14} \mathrm{C}\right.$ yr, $\left.2 \sigma\right)$; and $3)$ subtropical South Pacific $\left(266.8 \pm 13.8{ }^{14} \mathrm{C} \mathrm{yr}, 2 \sigma\right)$. This uniformity suggests that reconstructions of South Pacific paleo-reservoir ages can be made by combining records from different sites within each region. We find that the average marine reservoir age at Vanuatu was $476 \pm 26{ }^{14} \mathrm{C}$ yr $(2 \sigma)$ during the Younger Dryas. This is about $150 \mathrm{yr}$ larger than today. Reservoir age variability during this time featured rapid large increases (up to $300{ }^{14} \mathrm{C} \mathrm{yr}$ ) and smaller decreases (up to $150{ }^{14} \mathrm{C} \mathrm{yr}$ ) over a period of a few decades. Reservoir age variability during the Younger Dryas is consistent with substantial ocean circulation and climatic changes on decadal to century timescales.

\section{ACKNOWLEDGMENTS}

The logistics required to collect these corals involved the cooperation and assistance of a large group of individuals. We would like to acknowledge the Institut de Recherche pour le Developpement (IRD) for field support necessary to collect the Marquesas coral. We would like to acknowledge the Explorer's Club, and John Loret in particular, for making possible the sampling of the Easter Island coral. We would like to acknowledge the Geological Survey of Vanuatu for assistance in collecting the Espiritu Santo Island core. We would like to acknowledge the government of Papua New Guinea, and Hugh Davies for assistance in collecting the Rabaul core. Many thanks to Bill Quirk for assistance with the X-ray images. This work was partially funded by NSF grants 0622305 and OCE 971054. University of Texas at Austin Institute for Geophysics Contribution No. 2072. 


\section{REFERENCES}

Bonjean F, Lagerloef GSE. 2002. Diagnostic model and analysis of the surface currents in the tropical Pacific Ocean. Journal of Physical Oceanography 32(10): 2938-54.

Brown T, Farwell GW, Grootes PM, Schmidt FH, Stuiver M. 1993. Intra-annual variability of the radiocarbon content of corals from the Galapagos Islands. Radiocarbon 35(2):245-51.

Burr GS, Beck JW, Taylor FW, Récy J, Edwards RL, Cabioch G, Corrège T, Donahue DJ, O’Malley JM. 1998. A coral-based radiocarbon calibration between 11,700 and 12,400 calendar years BP derived from ${ }^{230} \mathrm{Th}$ ages of corals from Espiritu Santo Island, Vanuatu. Radiocarbon 40(3):1093-105.

Burr GS, Galang C, Taylor FW, Gallup C, Edwards RL, Cutler K, Quirk B. 2004. Radiocarbon results from a 13 kyr BP coral from the Huon Peninsula, Papua New Guinea. Radiocarbon 46(3):1211-24.

Cheng H, Edwards RL, Hoff J, Gallup CD, Richards DA, Asmerom Y. 2000. The half-lives of uranium-234 and thorium-230. Chemical Geology 169:17-33.

Corrège T, Gagan MK, Beck JW, Burr GS, Cabioch G, Cornec F. 2004. Interdecadal variation in the extent of South Pacific tropical waters during the Younger Dryas event. Nature 428(6986):927-9.

Craig H. 1954. Carbon 13 in plants and the relationship between carbon 13 and carbon 14 variations in nature. Journal of Geology 62:115-49.

Craig H. 1957. The natural distribution of carbon and the exchange time of carbon between the atmosphere and sea. Tellus 9:1-17.

Cutler KB, Gray SC, Burr GS, Edwards RL, Taylor FW, Cabioch F, Beck JW, Cheng H, Moore J. 2004. Radiocarbon calibration and comparison to $50 \mathrm{kyr} \mathrm{BP}$ with paired ${ }^{14} \mathrm{C}$ and ${ }^{230} \mathrm{Th}$ dating of corals from Vanuatu and Papua New Guinea. Radiocarbon 46(3):1127-60.

Donahue DJ, Linick TW, Jull AJT. 1990. Isotope-ratio and background corrections for accelerator mass spectrometry radiocarbon measurements. Radiocarbon 32(2):135-42.

Druffel ERM. 1981. Radiocarbon in annual coral rings from the eastern tropical Pacific Ocean. Geophysical Research Letters 8(1):59-62.

Druffel ERM, Griffin S. 1993. Large variations of surface ocean radiocarbon: evidence of circulation changes in the southwestern Pacific. Journal of Geophysical Research 98(C11):20,249-59.

Druffel ERM, Griffin S. 1995. Regional variability of surface ocean radiocarbon from southern Great Barrier Reef corals. Radiocarbon 37(2):517-24.

Druffel ERM. 1997. Geochemistry of corals: proxies of past ocean chemistry, ocean circulation, and climate. Proceedings of the National Academy of Sciences USA 94(16):8354-61.

Druffel ERM, Griffin S. 1999. Variability of surface ocean radiocarbon and stable isotopes in the southwestern Pacific. Journal of Geophysical Research
104(C10):23,607-13.

Druffel ERM, Griffin S, Beaupré SR, Dunbar RB. 2007. Oceanic climate and circulation changes during the past four centuries from radiocarbon in corals. Geophysical Research Letters 34: L09601, doi: 10.1029/ 2006GL028681.

Edwards RL, Chen JH, Wasserburg GJ. 1987. ${ }^{238}{ }^{U}-234$ U${ }^{230} \mathrm{Th}-{ }^{232} \mathrm{Th}$ systematics and the precise measurement of time over the past 500,000 years. Earth and Planetary Science Letters 81(2-3):175-92.

Edwards RL, Beck JW, Burr GS, Donahue DJ, Chappell JMA, Bloom AL, Druffel ERM, Taylor FW. 1993. A large drop in atmospheric ${ }^{14} \mathrm{C} /{ }^{12} \mathrm{C}$ and reduced melting in the Younger Dryas, documented with ${ }^{230} \mathrm{Th}$ ages of corals. Science 260(5110):962-8.

Fallon SJ, Guilderson TP. 2008. Surface water processes in the Indonesian throughflow as documented by a high-resolution coral $\Delta^{14} \mathrm{C}$ record. Journal of Geophysical Research 113: C09001, doi: 10.1029/ 2008JC004722.

Fallon SJ, Guilderson TP, Caldeira K. 2003. Carbon isotope constraints on vertical mixing and air-sea $\mathrm{CO}_{2}$ exchange. Geophysical Research Letters 30(24): 2289-92.

Franke J, Paul A, Schulz M. 2008. Modeling variations of marine reservoir ages during the last 45000 years. Climate of the Past 4(2):125-36.

Friedrich M, Remmele S, Kromer B, Hofmann J, Spurk M, Kaiser KF, Orcel C, Küppers M. 2004. The 12,460year Hohenheim oak and pine tree-ring chronology from Central Europe - a unique annual record for radiocarbon calibration and paleoenvironment reconstructions. Radiocarbon 46(3):1111-22.

Grottoli AG, Gille ST, Druffel ERM, Dunbar RB. 2003. Decadal timescale shift in the ${ }^{14} \mathrm{C}$ record of a central equatorial Pacific coral. Radiocarbon 45(1):91-9.

Guilderson TP, Schrag DP. 1998. Abrupt shift in subsurface temperatures in the tropical Pacific associated with changes in El Niño. Science 281(5374):240-3.

Guilderson TP, Schrag DP, Kashgarian M, Southon J. 1998. Radiocarbon variability in the western equatorial Pacific inferred from a high-resolution coral record from Nauru Island. Journal of Geophysical Research 103(C11):24,641-50.

Guilderson TP, Caldeira K, Duffy PB. 2000a. Radiocarbon as a diagnostic tracer in ocean and carbon cycle modeling. Global Biogeochemical Cycles 14(3):887902.

Guilderson TP, Schrag DP, Goddard E, Kashgarian M, Wellington GM, Linsley BK. 2000b. Southwest subtropical Pacific surface water radiocarbon in a highresolution coral record. Radiocarbon 42(2):249-56.

Guilderson TP, Schrag DP, Cane MA. 2004. Surface water mixing in the Solomon Sea as documented by a high-resolution coral ${ }^{14} \mathrm{C}$ record. Journal of Climate 17(5):1147-56

Hua Q, Barbetti M, Jacobsen GE, Zoppi U, Lawson EM. 
2000. Bomb radiocarbon in annual tree rings from Thailand and Australia. Nuclear Instruments and Methods in Physics Research B 172(1-4):359-65.

Hua Q, Barbetti M, Zoppi U, Chapman DM, Thomson B. 2003. Bomb radiocarbon in tree rings from New South Wales, Australia: implications for dendrochronology, atmospheric transport, and air-sea exchange of $\mathrm{CO}_{2}$. Radiocarbon 45(3):431-47.

Hughen KA, Baillie MGL, Bard E, Beck JW, Bertrand CJH, Blackwell PG, Buck CE, Burr GS, Cutler KB, Damon PE, Edwards RL, Fairbanks RG, Friedrich M, Guilderson TP, Kromer B, McCormac G, Manning S, Bronk Ramsey C, Reimer PJ, Reimer RW, Remmele S, Southon JR, Stuiver M, Talamo S, Taylor FW, van der Plicht J, Weyhenmeyer CE. 2004. Marine04 marine radiocarbon age calibration, 0-26 cal kyr BP. $R a-$ diocarbon 46(3):1059-86.

Matsumoto K, Sarmiento JL, Key RM, Aumont O, Bullister JL, Caldeira K, Campin J-M, Doney C, Drange H, Dutay J-C, Follows M, Gao Y, Gnanadesikan A, Gruber N, Ishida A, Joos F, Lindsay K, MaierReimer E, Marshall JC, Matear RJ, Monfray P, Mouchet A, Najjar R, Plattner G-K, Schlitzer R, Slater R, Swathi PS, Totterdell IJ, Weirig M-F, Yamanaka Y, Yool A, Orr JC. 2004. Evaluation of ocean carbon cycle models with data-based metrics. Geophysical Research Letters 31: L07303, doi: 10.1029/ 2003GL018970.

McCormac FG, Hogg AG, Blackwell PG, Buck CE, Higham TFG, Reimer PJ. 2004. SHCAL04 Southern Hemisphere calibration, 0-11.0 cal kyr BP. Radiocarbon 46(3):1087-92.

McGregor HV, Gagan MK, McCulloch MT, Hodge E, Mortimer G. 2008. Mid-Holocene variability in the marine ${ }^{14} \mathrm{C}$ reservoir age for northern coastal Papua New Guinea. Quaternary Geochronology 3(3):21325.

Meissner KJ. 2007. Younger Dryas: a data to model comparison to constrain the strength of the overturning circulation. Geophysical Research Letters 34: L21705, doi: 10.1029/2007GL031304.

Moore MD, Schrag DP, Kashgarian M. 1997. Coral radiocarbon constraints on the source of the Indonesian throughflow. Journal of Geophysical Research 102(C6):12,359-65.

Müller SA, Joos F, Edwards NR, Stocker TF. 2006. Water mass distribution and ventilation time scales in a costefficient, three-dimensional ocean model. Journal of Climate 19(21):5479-99.
Oeschger H, Siegenthaler U, Schotterer U, Gugelman A. 1975. A box diffusion model to study the carbon dioxide exchange in nature. Tellus 27:168-92.

Olsson IU. 1970. The use of oxalic acid as a standard. In: Olsson IU, editor. Radiocarbon Variations and Absolute Chronology. Nobel Symposium 12, Uppsala, 1115 August 1969. New York: John Wiley \& Sons. p 17.

Paterne M, Ayliffe LK, Arnold M, Cabioch G, TisneratLaborde N, Hatte C, Douville E, Bard E. 2004. Paired ${ }^{14} \mathrm{C}$ and ${ }^{230} \mathrm{Th} / \mathrm{U}$ dating of surface corals from the Marquesas and Vanuatu (sub-equatorial Pacific) in the 3000 to 15,000 cal yr interval. Radiocarbon 46(2): 551-66.

Petchey F, Anderson A, Zondervan A, Ulm S, Hogg A. 2008. New marine $\Delta \mathrm{R}$ values for the South Pacific Subtropical Gyre region. Radiocarbon 50(3):373-97.

Reimer RW, Reimer PJ. 2006. Marine reservoir corrections and the calibration curve. PAGES News 14(3): $12-3$.

Revelle R, Suess HE. 1957. Carbon dioxide exchange between atmosphere and ocean and the question of an increase of atmospheric $\mathrm{CO}_{2}$ during th past decades. Tellus 9:18-27.

Rodgers K, Aumont O, Madec G, Menkes C, Blanke B, Monfray P, Orr JC, Schrag DP. 2004. Radiocarbon as a thermocline proxy for the eastern equatorial Pacific. Geophysical Research Letters 31: L14314, doi: 10.1029/2004GL019764.

Schmidt A, Burr GS, Taylor FW, O’Malley J, Beck JW. 2004. A semiannual radiocarbon record of a modern coral from the Solomon Islands. Nuclear Instruments and Methods in Physics Research B 223-224:420-7.

Singarayer JS, Richards DA, Ridgwell A, Valdes PJ, Austin WEN, Beck JW. 2008. An oceanic origin for the increase of atmospheric radiocarbon during the Younger Dryas. Geophysical Research Letters 35: L14707, doi: 10.1029/2008GL034074.

Stuiver M, Braziunas TF. 1993. Modeling atmospheric ${ }^{14} \mathrm{C}$ influences and ${ }^{14} \mathrm{C}$ ages of marine samples to 10,000 BC. Radiocarbon 35(1):137-89.

Stuiver M, Polach H. 1977. Discussion: reporting of ${ }^{14} \mathrm{C}$ data. Radiocarbon 19(3):355-63.

Stuiver M, Pearson GW, Braziunas T. 1986. Radiocarbon age calibration of marine samples back to $9000 \mathrm{cal} \mathrm{yr}$ BP. Radiocarbon 28(2B):980-1021.

Toggweiler JR, Dixon K, Broecker WS. 1991. The Peru upwelling and the ventilation of the South Pacific thermocline. Journal of Geophysical Research 96(C11):20,467-97. 